\title{
Generall Entomology Occurrence of Phytophagous Scarabaeidae (Coleoptera) in a pasture area at the Balsamo municipality, São Paulo, Brazil
}

\author{
Flavio Terradas Menis ${ }^{\circledR \odot}$ \& Sérgio Roberto Rodrigues ${ }^{\circledR}$
}

Universidade Estadual de Mato Grosso do Sul, Cassilândia, MS

\author{
EntomoBrasilis 14: e928 (2021)
}

\author{
Edited by: \\ William Costa Rodrigues \\ Article History: \\ Received: 19.viii.2020 \\ Accepted: $14 . x$ ii. 2020 \\ Published: 25.i.2021

\section{Corresponding author:} \\ Flavio Terradas Menis \\ 乃 flavioterradas@gmail.com \\ Funding agencies: \\ $\&$ Without funding declared
}

\begin{abstract}
Pasture areas have been decreasing over the years in Brazil, largely due to the expansion of agricultural areas, mainly in the Southeast region. Natural or planted pastures are subject to attack by insects that can become pests depending on their level of infestation and among them are the Scarabaeidae beetles. The scarce information on the species of this family existing in the region of Bálsamo (São Paulo) makes a study on the occurrence of these species necessary, thus generating data that can contribute to identification and information on possible existing pest species. During September 2018 to August 2019, collections of phytophagous Scarabaeidae species were done in pasture areas with a light trap. A total of 446 adults from the subfamilies Dynastinae, Melolonthinae and Rutelinae were collected. In Dynastinae the genera Bothynus, Coelosis, Cyclocephala, Chalepides and Actinobolus were collected, in Melolonthinae the genera Plectris and Liogenys and in Rutelinae the genera Anomala, Geniates, Leucothyreus, Lobogeniates, Byrsopolis and Trizogeniates were found. Among the species collected, some are described as pests in crops, including pastures, such as Liogenys suturalis Blanchard, which was the species that had the largest number of individuals during the collection period, being indicated as a species worthy of more detailed studies.
\end{abstract}

Keywords: Dynastinae; Liogenys suturalis; Melolonthinae; Rutelinae; Soil pests.

\begin{abstract}
n Brazil, there are approximately 166 million ha covered by natural or planted pasture (Araújo et al. 2017). These areas have been decreasing in number due to the accelerated growth of agriculture areas, urbanization and reforestation (DIAS-FILHO 2014). According to the agricultural census of 2017, the percentage of occupied natural and planted pasture areas was of $45.4 \%$. In the state of São Paulo, out of the 16,512,145-ha available for agriculture, $29 \%$ were covered by pasture, out of which $19.4 \%$ were occupied by planted pastures. At the municipality of Bálsamo, the area available for agriculture is of 12,205 ha, out of which 3,267 ha are covered by pasture (IBGE 2017).
\end{abstract}

As in any kind of plantation, pastures suffer with insect attacks which may become pests and among these there are the Scarabaeidae beetles found at soy-bean and corn plantations (PÉrez-Agis et al. 2008; Oliveira et al. 2012), sugar cane (Coutinho et al. 2011), sunflower (CAmargo \& Amabile 2001), wheat (DA SiLVA Pereira \& Salvadori 2011) and pasture areas (Bonivardo et al. 2015; DuchinI et al. 2017). The larvae are often responsible for the observed plant damage. These immatures feed on roots, affecting the water-nutrient absorption system of the plants, resulting in decreasing of the plant stand and productivity of the plantations (ÁvILA et al. 2014).

There are Scarabaeidae species that stand out by the wide geographic occurrence and by the damaged caused to plantations (Rodrigues et al. 2011). At the soy-bean culture, the damaged caused by beetle larvae are known since 1980 (OliveIRA \& GARCIA 2003). At the Rio Grande do Sul state, plantations of black oath, linen, corn and sunflower suffered damages caused by Diloboderus abderus Sturm, one of the main pest species (SILVA \& Boss 2002; SiLVA \& Costa 2002; DaL

\section{Pra et al. 2011).}

Phyllophaga triticophaga (Morón \& Salvadori) have been observed causing damages to soy-bean, wheat, natural and planted pastures (Da Silva Pereira \& Salvadori 2011; Valmorbida et al. 2018).

Phyllophaga cuyabana Moser, causes damage to corn and soy-bean at the states of Paraná, Rio Grande do Sul, Goiás, Mato Grosso and Mato Grosso do Sul (Oliveira \& Garcia 2003; ÁvILA 2015).

Liogenys fusca (Blanchard), was observed damaging corn and soy-bean cultures at the Mato Grosso do Sul state (RodRIGUES et al. 2008; ÁvILA et al. 2014).

Cyclocephala putrida Burmeister, and Anomala testaceipennis Blanchard, are considered pests in pasture plantations at the San Luís province, Argentina (BonIVARdo et al. 2015), whilst Cyclocephala flavipennis Arrow, was identified as a pest in perennial pastures in the Lages region in the State of Santa Catarina (DucHINI et al. 2017). At Irrigated rice plantations at the Northern and Northeastern region, larvae of Euetheola humilis (Burmeister), were classified as an important pest species (SANTOS \& SANTIAGO 2014).

Not only larvae, but adults of phytophagous Scarabaeidae also may feed of leaves, flowers, pollen, secretions or plant remains (MAIA et al. 2013; ChERMAN \& Moron 2014) At the Aquidauana municipality, state of Mato Grosso do Sul, Nogueira et al. (2013) collected adults of two Cyclocephala species in a pasture area, namely Cyclocephala tucumana Brethes, and Cyclocephala melanocephala (Fabricius). RODRIGUEs et al. (2019) obtained adults of Anomala inconstans 
Burmeister, in a pasture area located at the Cassilândia municipality, state of Mato Grosso do Sul.

At the Brazilian Pampas region, VAlmorbida et al. (2018) collected 25 Scarabaeidae adults in natural and planted pastures, distributed in Cyclocephala, Dyscinetus, Diloboderus, Euetheola, Liogenys, Plectris and Leucothyreus.

However, not all phytophagous Scarabaeidae species are considered to be pests. There are some species considered to be benefic to the environment, such as Bothynus medon (Germar), Bothynus striatellus (Fairmaire), which builds soil galleries that facilitate water infiltrations and aid in the organic matter incorporation (SAlVAdORI \& OlIVEIRA 2001; SILVA \& SALVADORI 2004).

In the different regions of Brazil, different Scarabaeidae species are reported causing damage to cultivated plants as well as benefiting the local environment. Due to the scarce information on the entomofauna of the Bálsamo municipality area, the data on the phytophagous Scarabaeidae existing in the are limited. The data obtained in the present work is needed due to the expansions of local agriculture areas, being an important tool to predict which species might become potential pests and which can become a benefit to the local future plantations. Thus, the present work recorded the phytophagous Scarabaeidae species present in pasture areas of the Bálsamo municipality.

\section{MATERIAL AND METHODS}

The experiment was conducted at the São Luis rural property $\left(20^{\circ} 40^{\prime} 16.13^{\prime \prime} \mathrm{S}, 49^{\circ} 30^{\prime} 51.16^{\prime \prime} \mathrm{W}\right)$ at the municipality of Bálsamo, which has $149,881 \mathrm{~km}^{2}$ and is located at the Northwestern region of the state of São Paulo (Figure 1) (IBGE 2019).

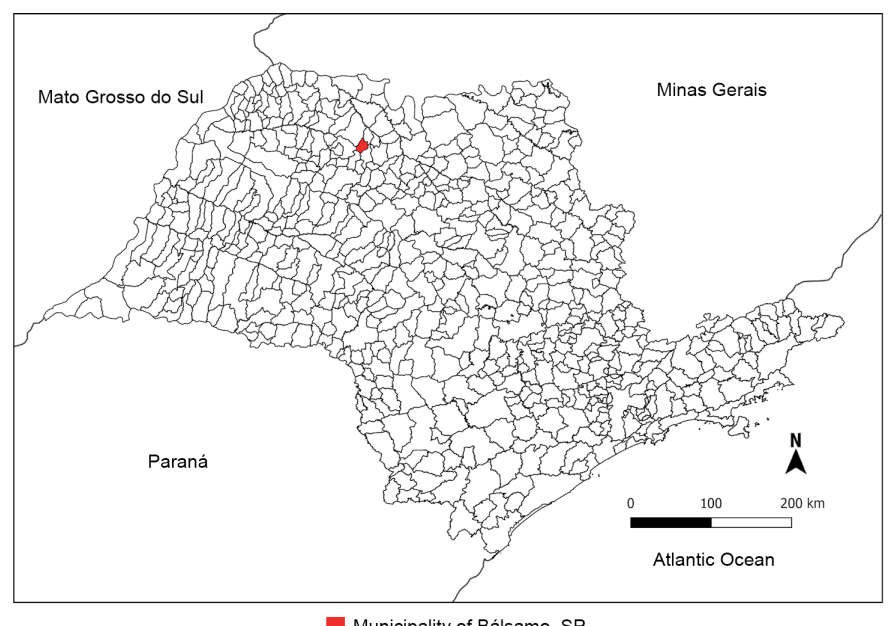

Municipality of Bálsamo, SP

Figure 1. Map displaying Bálsamo geographic location, state of São Paulo, Brazil.

The rural property has 80 ha of area, out of which 28 ha are of pasture, 39 ha of rubber tree and 11 ha of native forest, which is divided in three fragments. This Forest is found in areas of ecological tension, which is caused by the mix of two different kinds of vegetation, being classified as SN - Contact Savannah/Sazonal Forest (Figure 2) (IBGE 2019). The region has tropical climate Aw as Köppen's classification, with a rainy summer and dry winter, with mean temperature of $18^{\circ} \mathrm{C}$ in cooler days and $27^{\circ} \mathrm{C}$ in the warmer ones (RoLım et al. 2007). The mean temperature throughout the 51 collect weeks was of approximately $26^{\circ} \mathrm{C}$, the accumulated precipitation level was of $160 \mathrm{~mm}$ and the relative humidity with mean of 78\% (Figure 3). All meteorologic data were obtained at the "Instituto Nacional de Metereologia" (INMET 2019).

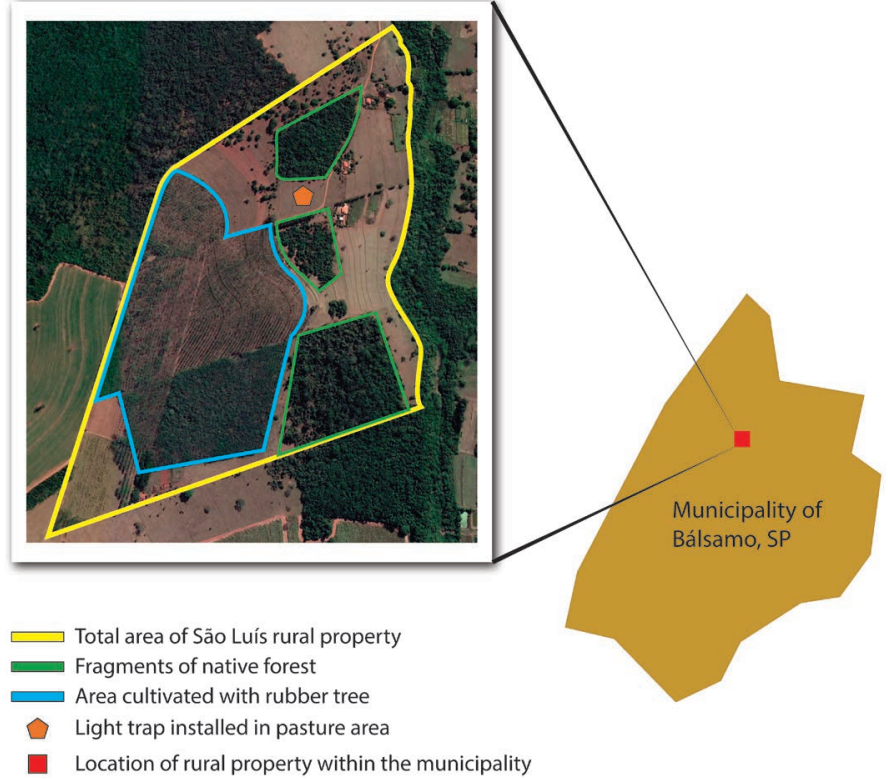

Figure 2. Research area located in the municipality of Bálsamo (SP) and place where the light trap is installed in a pasture area.

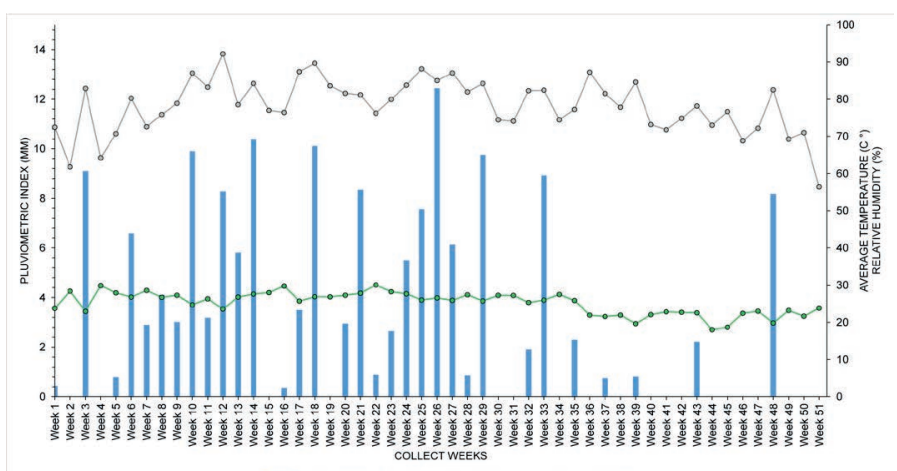

Figure 3. Meteorologic data of the Bálsamo Municipality (São Paulo), from September 7th 2018 to August 30rd 2019, obtained though the conventional meteorologic station of the "Instituto Nacional de Meteorologia" located at the municipality of Votuporanga, São Paulo.

At the pasture area cultivated with palisade grass, Urochloa brizantha cv., a light-trap of the "Luiz de Queiroz" type, made with steel foundation and collector cup made of PVC, with a 15 watts $6500 \mathrm{k}$ fluorescent white lamp was installed and turned on (Silveira Neto \& Silveira 1969). The collections were made once a week, every Friday, from 18:00 p.m. to 6:00 a.m. of the following day, from September 7th 2018 until August 30rd 2019, totalizing 51 weeks.

After being collected, the Scarabaeidae adults were stored in $300 \mathrm{~mL}$ plastic vials in 70\% glycerin alcohol, until brought to the laboratory of entomology of the "Universidade Estadual do Mato Grosso do Sul" (UEMS), campus of Cassilândia, where they were pinned, labeled sent and donate to the Dr. Juares Fuhrmann (Zoology Museum of "Universidade de São Paulo") and Dr. Paschoal Coelho Grossi ("Universidade Federal do Pernambuco") for identification.

\section{RESULTS AND DISCUSSION}

A total of 446 Scarabaeidae adults were collected, belonging to 19 species distributed into the Dynastinae, Melolonthinae e Rutelinae (Table 1). Out of the total, 12 species might become potential pests in plantations, such as species of the Cyclocephala, Liogenys, Anomala, Leucothyreus, Geniates, Plectris, Chalepides and Lobogeniates. Benefic species of the Bothynus and Coelosis were collected as well. A percentage of $99,5 \%$ of the adults were collected during September 
2018 until March 2019, coinciding with the rainy season of the Bálsamo region. During May 2019 to August of the same year, the occurrence of scarabaeidae dropped significantly, fact that may be connected to the dry season, which ranges from May to August (Figure 3).

In areas of natural pasture at the Brazilian Pampas, 28 species of Scarabaeidae were collected, distributed into the Dynastinae, Melolonthidae and Rutelinae (VALMORBIDA et al. 2018). DuchinI et al. (2017) identified four species of phytophagous Scarabaeidae in winter pastures of the Lages municipality, state of Santa Catarina. Cherman et al. (2014) observed the presence of five species in the Dynastinae, Melolonthinae and Rutelinae in pasture areas of the state of Rio Grande do Sul.

Bellow are listed the collected species and their respective subfamilies.

\section{Dynastinae}

There are approximately 800 species recorded for this subfamily (Moron et al. 2004).

\section{Bothynus}

A total of 18 adults of $B$. medon were collected during September until October, representing $4 \%$ of all insects collected. Pereira et al. (2013b) at the municipality of Aquidauana in the state of Mato Grosso do Sul, collected adults of $B$. medon during procreation-flight season, as the females captured had eggs ready to be laid and females ovipositing were observed in field. $B$. striatellus had a total of
28 collected adults, representing 6,2\% of all insects (Table 1).

Adults of $B$. medon e $B$. striatellus were collected by RIEHS (2006) in different areas of the Paraná state, with $B$. medon being the most collected. Riens (op. cit.) reported that $B$. medon occurred from December to February, differing from the present study (Table 1). B. striatellus was also collected during DecemberFebruary, differing from the present study, which collected the species at September, October and December (Table 1).

There are 28 species of Bothynus recorded for the world (DuARTE \& Grossi 2016). Adults of this genus are considered benefic to plantations, as they open galleries in the soil and facilitated water infiltrations, besides incorporating organic matter to the soil (OLIVEIRA et al. 2012).

\section{Coelosis}

A total of 47 adults of Coelosis were captured. They were identified as Coelosis bicornis (Leske) and C. biloba. Coelosis bicornis represented $10,5 \%$ of all insects (Table 1 ). Coelosis is compounded by seven species, all from South America with exception of Coelosis biloba (Linnaeus), which occur from Argentina México (ENDRÖDI 1985). Little is known about this genus, although there are records of $C$. bicornis found in degraded and flooded areas (GASCA et al. 2008).

An adult of C. biloba was collected in March (Table 1). This species usually builds its nest in ant nests, where its larvae feed from the fungi cultivated by the ants. Cannibalism of C. biloba adults on up to third instar larvae is also recorded (GAsca et al. 2008).

Table 1. Phytophagous Scarabaeidae species collected during September 7th 2018 to August 30rd 2019 with a light trap at the Bálsamo municipality.

\begin{tabular}{|c|c|c|c|c|c|c|c|c|c|c|c|c|c|}
\hline Species & Sep & Oct & Nov & Dec & Jan & Fev & Mar & Apr & Mai & Jun & Jul & Aug & Total \\
\hline \multicolumn{14}{|l|}{ Dynastinae } \\
\hline Bothynus medon & 15 & 3 & - & - & - & - & - & - & - & - & - & - & 18 \\
\hline Bothynus striatellus & 6 & 19 & - & 3 & - & - & - & - & - & - & - & - & 28 \\
\hline Coelosis bicornis & 3 & 6 & 26 & 6 & 2 & 1 & - & 1 & 1 & - & - & - & 46 \\
\hline Coelosis biloba & - & - & - & - & - & - & 1 & - & - & - & - & - & 1 \\
\hline Cyclocephala forsteri & - & - & 2 & - & - & - & - & - & - & - & - & - & 2 \\
\hline Cyclocephala melanocephala & - & 9 & 24 & - & 2 & 3 & 3 & - & - & - & - & - & 41 \\
\hline Cyclocephala putrida & - & - & - & - & 1 & 2 & - & - & - & - & - & - & 3 \\
\hline Cyclocephala sp. & 18 & 2 & - & - & - & - & - & - & - & - & - & - & 20 \\
\hline Cyclocephala mecynotarsis & - & 1 & - & - & - & - & - & - & - & - & - & - & 1 \\
\hline Chalepides fuliginosus & - & - & - & - & - & - & 1 & - & - & - & - & - & 1 \\
\hline Actinobolus trilobus & - & 4 & - & - & - & - & - & - & - & - & - & - & 4 \\
\hline Subtotal & & & & & & & & & & & & & 165 \\
\hline \multicolumn{14}{|l|}{ Melolonthinae } \\
\hline Plectris sp & - & - & - & - & - & - & 1 & - & - & - & - & - & 1 \\
\hline Liogenys suturalis & 39 & 71 & 8 & - & - & - & - & - & - & - & - & - & 118 \\
\hline Subtotal & & & & & & & & & & & & & 119 \\
\hline \multicolumn{14}{|l|}{ Rutelinae } \\
\hline Anomala testaceipennis & - & - & - & - & - & - & 1 & - & - & - & - & - & 1 \\
\hline Geniates borelli & - & 5 & 4 & - & - & - & - & - & - & - & - & - & 9 \\
\hline Leucothyreus alvarengai & - & 13 & 16 & 3 & - & 2 & 5 & - & - & - & - & - & 39 \\
\hline Lobogeniates sp & - & - & - & - & - & - & 1 & - & - & - & - & - & 1 \\
\hline Byrsopolis quadraticeps & - & 1 & 32 & 9 & - & - & - & - & - & - & - & - & 42 \\
\hline Trizogeniates planipennis & 14 & 51 & 5 & - & - & - & - & - & - & - & - & - & 70 \\
\hline Subtotal & & & & & & & & & & & & & 162 \\
\hline Total & & & & & & & & & & & & & 446 \\
\hline
\end{tabular}




\section{Cyclocephala}

Adults of Cyclocephala have Neotropical distribution of its 300 species (Ratcliffe \& Cave 2002; Oliveira \& Almeida Neto 2018). In Brazil, 82 of these species were recorded (Morón 2004).

A higher number of species were collected for this genus, with a total of five (Table 1). At the Brazilian Pampas, in areas of natural and cultivated pasture, solely Cyclocephala modesta Burmeister was collected (VALMORBIDA et al. 2018).

A total of 67 Cyclocephala were collected from September to March. Among the collected species, two adults of Cyclocephala forsteri Endrodi, were identified, both collected during November (Table 1). Adults of $C$. forsteri were observed feeding on flowers of the palm tree Acronomia aculeata, causing the falling of the floral buds (OLIVEIRA \& ÁvILA 2011) and causing damage to soy-bean plantations (SANTOS \& ÁvILA 2007).

A total of 41 C. melanocephala specimens were collected, representing $9 \%$ of all insects (Table 1). At the rubber tree plantation, it was observed an adult swarming of $C$. melanocephala, an atypical behavior as its adults usually feed on flowers and may contribute to their pollination (TAírA et al. 2014; RODRIGUEs et al. 2018). This fact may explain the relatively high number of specimens of this species, as the studied area has part of it covered by the rubber tree Hevea brasiliensis.

Three C. putrida were identified, all collected during January and February (Table 1), corroborating the results of SALDANHA et al. (2020), whom collected the same species with the same light trap model of the present study during the same months, what may indicate that this species has its flight season during this period. As in the present study, SaldanHA et al. (op. cit.) also collected during warmer temperatures $\left(23^{\circ}\right.$ to $28^{\circ}$ ) at Cassilândia (vs. $27^{\circ}$ at Bálsamo) (Figure 2). C. putrida was also collected in a cultivated pasture area and in a natural vegetation area at the Rio Grande do Sul State (Cherman et al. 2014).

An adult of Cyclocephala mecynotarsis Hohne, was collected during October. This species was also collected in the Amazonia, at the municipality of Itacoatiara, State of Amazonas (Andreazze \& FonseCA 1998). In Brazil, C. mecynotarsis was described as a peach, pear and nectarine pest (BEVILAQUA et al. 2012).

\section{Chalepides}

A single specimen of Chalepides fuliginosus (Burmeister) was collected during March (Table 1). There are few studies about this genus, although Chalepides dytiscoides Arrow is considered to be a species with agricultural value at the regions of the dry and humid Caribbean at Colombia (PARDo-LocARno et al. 2012). C. fuliginosus was also collected with light trap at Campos Gerais, state of Paraná (Grossı et al. 2012).

\section{Actinobolus}

During October, four adults of Actinobolus trilobus Lüderwaldt were collected (Table 1). Larvae of this species were observed living in termite nests of the Nasutitermes (LUEDERWALDT 1911). Furthermore, its larvae feed on the termite nest wall (NEITAMoreno \& Ratcliffe 2011).

\section{Melolonthinae}

In this subfamily, there are the species which cause the most damage to plantations. Adults feed on flower and leaves, whilst the larvae feed on roots and stalks of grass, corn, pasture and wheat (RITCHER 1966). There are approximately 19, recorded species (Morón et al. 2014).

\section{Liogenys}

A total of 118 adults of Liogenys suturalis Blanchard were collected, representing $26,4 \%$ of all insects (Table 1 ). Ferreira et al. (2018) obtained higher numbers of this species during their collections at Aquidauana, with similar climatic conditions, at the rainy season from September to April, with similar temperatures ( $33^{\circ}$ at Aquidauana and $29^{\circ}$ at Bálsamo). This may be an indicative that this species has preference for warmer temperatures.

Several species of this genus are considered to be pests in different plantations. Liogenys suturalis is considered to be a pest of corn, wheat and oath at the Center-West region of Brazil (SANTOS \& ÁvILA 2009).

\section{Plectris}

An adult of Plectris were collected in March (Table 1). According to VILLEGAS et al. (2008), in pasture areas at Risaralda, Colombia, the period of higher abundance of species of this genus are during April and May, differing from what happened in the present study. Cherman et al. (2014) also found a morphotype of Plectris, but at larval stage, at the planaltina region of the Rio Grande do Sul, in plantation areas. Although 232 species of this genus are recorded to Brazil (Evans \& SMITH 2009), this genus was not expressive during collection period.

\section{Rutelinae}

This is the second largest subfamily of Melolonthidae, with 4,197 described species (Morón \& Ramírez-Ponce 2012).

\section{Anomala}

An specimen of $A$. testaceipennis was collected during March (Table 1). Rodrigues et al. (2014) reported mating behavior of this species during February at Aquidauana. Both collections of the present work and at Rodrigues et al. (2014) happened during rainy season. Although it had only a single specimen, A. testaceipennis may cause damages to several plantations, among them there are corn and pasture (ÁvILA \& SANTOS 2009; RODRIGUES et al. 2011). This species had it mating behavior observed and it was concluded that it starts flying at six p.m. and finish the activities around six a.m. (Rodrigues et al. 2014), coinciding with the time period in which the light trap was on.

\section{Leucothyreus}

A total of 39 adults of Leucothyreus alvarengai Frey, representing $8.7 \%$ of all insects (Table 1 ), were collected.

Some Leucothyreus species are considered pests, as described by MARTINEZ et al. (2013), which reported Leucothyreus femoratus Burmeister, attacking palm tree plantations.

According to Pereira et al. (2013a), adults of L. alvarengai have their flight season from September to January, partially coinciding with the collection period of the present study, as adults were collected mainly in October, despite the species kept being collected until March in lower numbers (Table 1). The collection of this species might be related to the presence of near sugar cane plantations, as CoutinHo (2015) reported the presence of $L$. alvarengai in sugar cane plantations at the region of Nova Andradina and Naviraí at Mato Grosso do Sul. However, the present recorded the presence of this species during October and November, instead of December as in CoUnTINHO (2015). L. alvarengai was also collected by DANTAS et al. (2018) in forest regions of Sergipe.

\section{Geniates}

A total of nine adults of Geniates borelli Camerano, were collected and represented $2 \%$ of all insects (Table 1 ). 
As observed, adults were recorded during October and November, similarly to the results of RodRIGUEs et al. (2012), at Aquidauana, MS, in which 1,918 of G. borelli were captured with a light trap from September to November 2006. Imatures of G. borelli were found in plantation succession system in which corn was cultivated during summer at February (RODRIGUEs et al. 2011), with the presence during this time period possibility related to the flight season, which usually happens from September do December.

\section{Lobogeniates}

A specimen of Lobogeniates sp. was collected in March (Table 1). Adults of Lobogeniates are described as banana, rice and pasture pests at the Colombian Caribbean region (PARDoLoCARNo et al. 2012).

\section{Trizogeniates}

A total of 70 adults of Trizogeniates planipennis Ohaus were collected. This species represented $15.6 \%$ of all insects (Table 1). The occurrence of $T$. planipennis was also recorded at Bahia (Ferreira et al. 2018).

\section{Byrsopolis}

A total of 42 specimens of Byrsopolis quadraticeps Blanchard, representing $9,4 \%$ of all specimens were collected (Table 1 ). The high incidence of this species during collection period might be related to its wide distribution, which according to Carvalmo \& Grossi (2018) ranges the states of Goiás, Minas Gerais, São Paulo and Federal District.

The raining and dry season might influence the behavior of the Scarabaeidae, as the highest numbers resulted during the rainy season (September to April) and the lowest numbers during the dry season (From May to August).

The phytophagous Scarabaeidae species present at pasture area of the Bálsamo is majoritarely compounded by species that might become pests to cultures cultivated at the region. Among the species considered with great potential of becoming a pest, L. suturalis was the most expressive with 118 specimens. This species is described as pest to plantations.

The presence of benefic phytophagous Scarabaeidae such as $B$. medon, $B$. striatellus and $C$. bicornis at the region is an important factor to soil nutrition and ecosystem equilibrium.

\section{REFERENCES}

Andreazze, R \& CRV Fonseca, 1998. Dinastíneos (Coleoptera, Scarabaeoidea, Melolonthidae) em uma área de terra firme na Amazônia Central, Brasil. Acta Amazonica, 28: 5966. DOI: https://doi.org/10.1590/1809-43921998281066

Araújo, FM, AS Faria, LG Ferreira Junior \& SHM Nogueira, 2017. Distribuição e avaliação da acuidade espacial dos mapeamentos da área de pastagem para o Brasil. XVIII Simpósio Brasileiro de Sensoriamento Remoto (SBSR), 18: 7232-7239. Available on: <https://proceedings.science/ sbsr/papers/distribuicao-e-avaliacao-da-acuidadeespacial-dos-mapeamentos-da-area-de-pastagem-parao-brasil>.

Ávila, CJ, 2015. Manejo integrado das principais pragas que atacam a cultura do milho no país. Visão Agrícola, 13: 102106.

Ávila, CJ, LM Vivian \& V Santos, 2014. Controle do Coró Liogenys fusca (Blanchard) (Coleoptera: Melolontidae) com Inseticidas Aplicados nas Sementes e no Sulco de Semeadura da Soja (Glycine max). BioAssay, 9: 2. DOI: https://doi.org/10.14295/ba.v9.137

Ávila, CJ \& V Santos, 2009. Corós associados ao sistema plantio direto no Estado de Mato Grosso do Sul. Dourados, MS:
Embrapa Agropecuária Oeste (Documentos).

Bevilaqua, MVO, AR Meneses, AQ Costa, RB Querino, CM de Oliveira, LS Carvalho, FZ Vaz-de-Mello \& MR Frizzas, 2012. Ocorrência de Scarabaeoidea (Coleoptera, Insecta) em uma área de cerrado no Piauí, Brasil. Anais do XXIX Congresso Brasileiro de Zoologia, 19: 1349-1349.

Bonivardo, SL, AN Martinez, G Perssi Magna \& A Pérez Suarez, 2015. Relevamiento de escarabeidos (Insecta, Coleoptera) em pastizal natural, pasto llorón y maiz, em el este de la província de San Luis (Argentina). FAVE Sección Ciencias Agrarias, 14: 1-8. DOI: https://doi.org/10.14409/ fa.v14i2.5718

Camargo, AJA \& RF Amabile, 2001. Identificação das principais pragas do girassol na região centro-oeste. Brasília, EMBRAPA (Comunicado Técnico, 50).

Carvalho, TG \& PC Grossi, 2018. Description of a second species of the genus Moronius Grossi \& Vaz-de-Mello, 2015 (Coleoptera: Scarabaeidae: Rutelinae: Rutelini). Zootaxa, 4434: 369- 372. DOI: https://doi.org/10.11646/ zootaxa.4434.2.7

Cherman, MA, MA Morón, JR Salvadori, E Dal Prá \& JVC Guedes, 2014. Análise populacional de corós-praga e de outras espécies no planalto do Rio Grande do Sul. Ciência Rural, 44: 2095-2102. DOI: https://doi.org/10.1590/0103$8478 \mathrm{cr} 20131443$

Cherman, MA \& MA Morón, 2014. Validación de la familia Melolonthidae Leach, 1819 (Coleoptera: Scarabaeoidea). Acta Zoologica Mexicana, 30: 201-220. DOI: https://doi.org/10.21829/azm.2014.301139

Coutinho, GV, SR Rodrigues, EC Cruz \& AR Abot, 2011. Bionomic data and larval density of Scarabaeidae (Pleurosticti) in sugarcane in the central region of Mato Grosso do Sul, Brazil. Revista Brasileira de Entomologia, 55: 389-385. DOI: https://doi.org/10.1590/S0085-56262011005000038

Coutinho, GV, 2015. Diversidade, aspectos biológicos e comportamentais de Melolonthidae encontrados em canaviais da região sul de Mato Grosso do Sul. Tese (Doutorado em Entomologia e Conservação da Biodiversidade). Universidade Federal da Grande Dourados.

Da Silva Pereira, PRV \& JR Salvadori, 2011. Pragas da lavoura de trigo, pp 263-283. In: Pires, JLF, L Vargas \& GR Cunha (Org.). Trigo no Brasil. 1ed. Passo Fundo, RS: Embrapa Trigo.

Dal Pra, E, JVC Guedes, MA Cherman, AH Jung, SJP da Silva \& GG Ribas, 2011. Uso da geoestatística para caracterização da distribuição espacial de larvas de Diloboderus abderus. Ciência Rural, 41: 1689-1694. DOI: https://doi.org/10.1590/ S0103-84782011001000002

Dantas, JO, NA Ferreira, IR Oliveira, MO Alves, GT Ribeiro \& TG Araújo-Piovezan, 2018. Edge effects on beetle assemblages in an Atlantic forest fragment and pasture in Sergipe, Brazil. EntomoBrasilis, 11: 26-32. DOI: https://doi.org/10.12741/ebrasilis.v11i1.739

Dias-Filho, MB, 2014. Diagnóstico das pastagens no Brasil. Belém: Embrapa Amazônia Oriental, (Documentos 402).

Duarte, PRM \& PC Grossi, 2016. Rediscovery of Bothynus cribrarius (Fairmaire) (Coleoptera, Melolonthidae, Dynastinae, Pentodontini): description of the male and precise location data. Revista Brasileira de Entomologia, 60: 290-292. DOI: https://doi.org/10.1016/j.rbe.2016.07.001

Duchini, PG, JR Echeverria, LF Americo, GC Guzatti, MA Cherman \& AF Sbrissia, 2017. White grubs (Cyclocephala flavipennis) damaging perennial winter pastures in the South Region of Brazil. Ciência Rural, 47: e20160662. DOI: https://doi.org/10.1590/0103-8478cr20160662

Endrödi, S, 1985. The Dynastinae of the World. W. Junk, Dordrecht, Netherlands.

Evans, AV \& ABT Smith, 2009. An electronic checklist of the new world chafers (Coleoptera: Scarabaeidae: Melolonthinae). Electronically Published, 3: 353. Available on: 
<http://unsm-ento.unl.edu/SSSA/nwmelos.htm>.

Ferreira, AS, LM Almeida, F Bravo \& PC Grossi, 2018. Um checklist dos Rutelinae MacLeay, 1819 (Coleoptera, Melolonthidae) da Bahia, Brasil. Biota Neotropica, 18: e20170476. DOI https://doi.org/10.1590/1676-0611bn-2017-0476

Gasca, HJA, CRV Fonseca \& BC Ratcliffe, 2008. Synopsis of the Oryctini (Coleoptera: Scarabaeidae: Dynastinae). Insecta Mundi, 61: 1-62.

Grossi, P, FWT Leivas \& LM Almeida, 2012. Dynastinae (Coleoptera: Scarabaeoidea: Melolonthidae) dos Campos Gerais, Paraná, Brasil, pp. 108-114. In: Carpanezzi OTB \&JB Campos (Org.). Coletânea de Pesquisas Parques Estaduais de Vila Velha, Cerrado e Guartelá. 1ed. Curitiba: IA.

IBGE, 2017. Instituto Brasileiro de Geografia e Estatística. Censo agropecuário 2017. Available on: <https://censos. ibge.gov.br/agro/2017/resultados-censo-agro-2017. html>. [Access: 30.xi.2020].

IBGE, 2019. Instituto Brasileiro de Geografia e Estatística. Biomas Continentais do Brasil. Available on: <https:// www.ibge.gov.br/geociencias/informacoes-ambientais/ vegetacao.html>. [Access: 30.xi.2020].

INMET, 2019. Instituto Nacional de Meteorologia. Bancos de Dados Meteorológicos. Available on: <https://bdmep. inmet.gov.br/>. [Access: 2.ix.2019].

Luederwaldt, H, 1911. Quatro lamellicorneos termitophilos. Revista Museu Paulista, 8: 405- 413.

Maia, ACD, M Gibernau, AT Carvalho, EG Gonçalves \& C Schlindwein, 2013. The cowl does not make the monk: scarab beetle pollination of the Neotropical aroid Taccarum ulei (Araceae: Spathicarpeae). Biological Journal of the Linnean Society. 108: 22-34. DOI: https://doi.org/10.1111/ j.1095-8312.2012.01985.x

Martínez, LC, A Plata-Rueda, JC Zanuncio \& JE Serrao, 2013. Leucothyreus femoratus (Coleoptera: Scarabaeidae): Feeding and Behavioral Activities as an Oil Palm Defoliator. The Florida Entomologist, 96: 55-63. DOI: https://doi.org/10.1653/024.096.0107

Morón, MA, 2004. Melolontídeos edafícolas, pp. 133-166 In: Salvadori JR, CJ Ávila \& MT Silva (Eds.). Pragas de Solo no Brasil. Embrapa Trigo, Passo Fundo, Brazil.

Morón, MA \& A Ramírez-Ponce, 2012. Mesoamerican genera of Anomalini (Coleoptera: Melolonthidae: Rutelinae): A brief review. Trends in Entomology, 8: 97-114.

Morón, MA, G Nogueira, CV Rojas-Gómez \& R Arce-Pérez, 2014. Biodiversidad de Melolonthidae (Coleoptera) en México. Revista Mexicana de Biodiversidad, 85: 298-302. DOI: https://doi.org/10.7550/rmb.31834

Neita-Moreno, JC \& BC Ratcliffe, 2011. Immature stages of Homophileurus tricuspis Prell (Coleoptera: Scarabaeidae: Dynastinae: Phileurini) with notes on natural history and distribution in Colombia. Zootaxa, 2915: 20-28. DOI: https://doi.org/10.11646/zootaxa.2915.1.2

Nogueira, GAL, SR Rodrigues \& EF Tiago, 2013. Biological aspects of Cyclocephala tucumana Brethes, 1904 and Cyclocephala melanocephala (Fabricius, 1775) (Coleoptera: Scarabaeidae). Biota Neotropica, 13: 86-90. DOI: https://doi.org/10.1590/S1676-06032013000100009

Oliveira, HN \& CJ Ávila, 2011. Ocorrência de Cyclocephala forsteri em Acronomia aculeata no Estado de Mato Grosso do Sul. Pesquisa Agropecuária Tropical, 41: 293-295. DOI: https://doi.org/10.5216/pat.v41i2.8769

Oliveira, LJ \& MA Garcia, 2003. Flight, feeding and reproductive behavior of Phyllophaga cuyabana (Moser) (Coleotera: Melolonthidae) adults. Pesquisa Agropecuária Brasileira, 38: 179-186. DOI: https://doi.org/10.1590/S0100204X2003000200003

Oliveira, LJ, S Roggia, JR Salvadori, CJ Ávila, PM Fernandes \& CM Oliveira, 2012. Insetos que atacam raízes e nódulos da soja, pp. 75-144. In: Hoffmann-Campo, CB, BS CorrêaFerreira \& F Moscardi (Org.). Soja: manejo integrado de insetos e outros artrópodes-praga. 1ed. Londrina, PR: Embrapa Soja. Available on: <http://www.cnpso.embrapa. br/artropodes/Capitulo2.pdf>

Oliveira, VC \& LC Almeida Neto, 2018. Polinização de Victoria amazônica (Nymphaeaceae) por besouros em condições ex situ no Jardim Botânico Municipal de Bauru/SP. Rodriguesia, 69: 945-949. DOI: https://doi.org/10.1590/2175-7860201869247

Pardo-Locarno, LC, González SJC, Pérez CCR, Yepes, F \& Fernández, C, 2012. Escarabajos de importancia agrícola (Coleoptera: Melolonthidae) en la región caribe colombiana: Registros y propuestas de manejo. Boletín del Museo Entomológico Francisco Luis Gallego, 4: 7-23.

Pereira, AF, SR Rodrigues \& MA Moron, 2013a. Biological aspects of Leucothyreus alvarengai Frey and Leucothyreus aff. semipruinosus Ohaus (Coleoptera, Melolonthidae, Rutelinae) in crop succession at central Brazil. Revista Brasileira de Entomologia, 57: 323-328. DOI: https://doi.org/10.1590/S0085-56262013005000028

Pereira, AF, SR Rodrigues \& S Ide, 2013b. Biology and Description of the Third Instar of (Germar, 1824) (Coleoptera: Scarabaeidae: Dynastinae). The Coleopterists Bulletin, 67: 328-334. DOI: https://doi.org/10.1649/0010065x-67.3.328

Pérez-Agis, SE, MA Morón, MB Nájera-Rincón, E LópezBarbosa \& M Vázquez-García, 2008. Analisis de diversidad del complejo "gallina ciega" (Coleoptera: Melolonthidae) en dos sistemas de produccion tradicional de maiz em la region Purhepecha, Michoacan. Acta Zoológica Mexicana, 24: 221-235. DOI: https://doi.org/10.21829/ azm.2008.241633

Ratcliffe, BC \& RD Cave, 2002. New species of Cyclocephala from Honduras and El Salvador (Coleoptera: Scarabaeidae: Dynastinae: Cyclocephalini). The Coleopterists Bulletin, 56: 152-157. DOI: https://doi.org/10.1649/0010-065x(2002)05 6[0152:nsocfh]2.0.co;2

Riehs, PJ, 2006. Fenologia de algumas espécies do gênero Bothynus (Coleoptera, Scarabaeidae) do Leste e CentroOeste do Paraná, Brasil. Revista de Ciências Exatas e Naturais, 8: 125-144.

Ritcher, PO, 1966. White grubs and their allies. Oregon State University Press, Corvallis.

Rodrigues, SR, CL Barbosa, A Puker, AR Abot \& S Ide, 2008. Occurrence, biology and behavior of Liogenys fuscus Blanchard (Insecta, Coleoptera, Scarabaeidae) in Aquidauana, Mato Grosso do Sul, Brazil. Revista Brasileira de Entomologia, 52: 637-640. DOI: https://doi.org/10.1590/ S0085-56262008000400015

Rodrigues, SR, JI Carmo, VS Oliveira, EF Tiago \& TL Taíra, 2011. Ocorrência de larvas de scarabaeidae fitófagos (Insecta: Coleoptera) em diferentes sistemas de sucessão de culturas. Pesquisa Agropecuária Tropical, 41: 87-93. DOI: https://doi.org/10.5216/pat.v41i1.7698

Rodrigues, SR, CL Barbosa, AR Abot, AR \& S Ide, 2012. Occurrence of adults and biological aspects of Geniates borelli Camerano (Coleoptera, Scarabaeidae, Rutelinae) in Aquidauana, MS, Brazil. Revista Brasileira de Entomologia, 56: 315-318. DOI: https://doi.org/10.1590/S008556262012005000035

Rodrigues, SR, ES Gomes \& JMS Bento, 2014. Sexual Dimorphism and Mating Behavior in Anomala testaceipennis. Journal of Insect Science, 14: 210-210. DOI: https://doi.org/10.1093/jisesa/ieu072

Rodrigues, SR, CAF Barbosa, J Fuhrmann \& RA Amaro, 2018. Mating behavior and description of immature stages of Cyclocephala melanocephala (Fabricius, 1775) (Coleoptera: Scarabaeidae: Dynastinae), identification key and remarks on known immatures of Cyclocephalini species. Revista Brasileira de Entomologia, 62: 205-219. DOI: https://doi.org/10.1016/j.rbe.2018.07.001

Rodrigues, SR, J Fuhrmann \& RA Amaro, 2019. Aspects 
of mating behavior and antennal sensilla in Anomala inconstans Burmeister, 1844 (Coleoptera: Scarabaeidae: Rutelinae). Biota Neotropica, 19: e20180664. DOI: https://doi.org/10.1590/1676-0611-bn-2018-0664

Rolim, GS, MBP Camargo, DG Lania \& JFL Moraes, 2007. Classificação climática de Koppen e de Thornthwaite e sua aplicabilidade na determinação de zonas agroclimáticas para o Estado de São Paulo. Bragantia, 66: 711-720. DOI: https://doi.org/10.1590/S0006-87052007000400022

Saldanha, FG, SR Rodrigues, RA Amaro \& J Fuhrmann, 2020. Description of mating behavior, life cycle, and antennal sensilla of Cyclocephala putrida Burmeister, 1847 (Coleoptera, Scarabaeidae, Dynastinae). Biota Neotropica, 20: e20200973. DOI: https://doi.org/10.1590/1676-0611bn-2020-0973

Salvadori, JR \& LJ Oliveira, 2001. Manejo de corós em lavouras sob plantio direto. Passo Fundo: Embrapa Trigo (Série Documentos. Embrapa Trigo, 35).

Santos, V \& CJ Ávila, 2007. Aspectos biológicos de Cyclocephala forsteri Endrodi, 1963 (Coleoptera: Melolonthidae) no estado do Mato Grosso do Sul. Revista de Agricultura, 82: 298-303. DOI: https://doi.org/10.37856/bja.v82i3.1470

Santos, V \& CJ Ávila, 2009. Aspectos biológicos e comportamentais de Liogenys suturalis Blanchard (Coleoptera: Melolonthidae) no Mato Grosso do Sul. Neotropical Entomology, 38: 734-740. DOI: https://doi.org/10.1590/S1519-566X2009000600005

Santos, V \& CJ Ávila, 2009. Ocorrência de parasitismo em larvas de Liogenys suturalis Blanchard, 1851 (Coleoptera: Melolonthidae) por Ptilodexia Brauer \& Bergenstamm, 1889 (Diptera: tachinidae). Arquivos do Instituto Biológico, 76: 745-748.

Santos, AB \& CM Santiago, 2014. Informações técnicas para a cultura do arroz irrigado nas regiões Norte e Nordeste do Brasil. Santo Antônio de Goiás: Embrapa Arroz e Feijão (Documentos 279).

Silva, MTB \& EC Costa, 2002. Nível de controle de Diloboderus abderus em aveia preta, linho, milho e girassol. Ciência Rural, 32: 7-12. DOI: https://doi.org/10.1590/S010384782002000100002

Silva, MTB \& A Boss, 2002. Controle químico de larvas de Diloboderus abderus com inseticidas em trigo. Ciência Rural, 32: 191-195. DOI: https://doi.org/10.1590/S010384782002000200002

Silva, MTB \& JR Salvadori, 2004. Coró-das-pastagens, pp. 191210 In: Salvadori, JR, CJ Ávila \& MTB Silva (Ed.). Pragas de solo no Brasil. Passo Fundo: Embrapa Trigo; Dourados: Embrapa Agropecuária Oeste; Cruz Alta: Fundacep Fecotrigo.

Silveira Neto, S \& AC Silveira, 1969. Armadilha luminosa modelo "Luiz de Queiroz". O Solo. 51: 19-21.

Taíra, TL, PCG Assunção, GM Silva \& SR Rodrigues, 2014. Ocorrência de Cyclocephala melanocephala (Coleoptera: Scarabaeidae) em seringueira. Revista de Agricultura Neotropical, 1: 80-82. DOI: https://doi.org/10.32404/rean. v1 i2.231

Valmorbida, I, MA Cherman, DS Jahn \& JVC Guedes, 2018. Abundance and Diversity in the Melolonthidae community in cultivated and natural grassland areas of the brazilian pampa. Environmental Entomology, 47: 1064-1071. DOI: https://doi.org/10.1093/ee/nvy109

Villegas, NP, A Gaigl, \& ELF Vallejo, 2008. El complejo chisa (Coleoptera: Melolonthidae) asociado a cebolla y pasto en Risaralda, Colombia. Revista Colombiana de Entomología, 34: 82-89.

$\star \star \star * * \star * * * *$
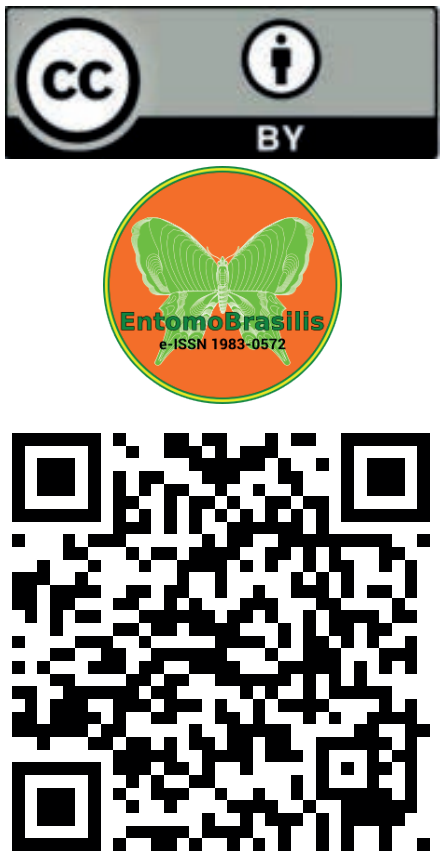